\title{
FACTORS AFFECTING "IN VITRO" PLANT DEVELOPMENT AND ROOT COLONIZATION OF SWEET POTATO BY GLOMUS ETUNICATUM BECKER \& GERD.
}

\author{
Wellington Bressan* \\ Embrapa Milho e Sorgo, Departamento de Microbiologia, Sete Lagoas, MG, Brasil \\ Submitted: August 28, 2000; Returned to authors for correction: May 23, 2001; Approved: February 25, 2002
}

\begin{abstract}
Nutrients media (Murashige \& Skoog, Hoagland \& Arnon and White's media) supplemented or not with sucrose and substrates (vermiculite, agar and natrosol) were tested for their effects on plant development and root colonization of micropropagated sweet potato, cv. White Star, by Glomus etunicatum Becker \& Gerdemann (isolate INVAM FL S329). Addition of sucrose (3\%) did not affect plant development. However, hyphal growth and root colonization were depressed. Contrasting responses to media nutrient concentration were observed for plant height, root colonization, and hyphal growth. The highest concentration of nutrients in Murashige \& Skoog medium improved plant development, but this medium decreased hypha growth and inhibited root colonization. Plants growing in vermiculite substrate had higher ( $\mathrm{p} £ 0.05)$ development and mycorrhizal root colonization than those growing in agar or natrosol. The results indicate that colonization of micropropagated sweet potato by arbuscular mycorrhizal fungi is affected by media composition and type of substrate.
\end{abstract}

Key words: arbuscular mycorrhiza, micropropagation, media composition, substrate

\section{INTRODUCTION}

Axenically produced mycorrhizal plants have been used to study the effect of externally supplied organic and inorganic phosphate sources on the incidence, extent and anatomy of infection (10) and also to measure the rate of movement of phosphate ions via the external mycelium of an infected root system. Plants growing in this way can be used to examine changes in the host brought about by arbuscular mycorrhizal (AM) infection which are not attributed to the presence of any other microorganism.

Under axenic conditions special attention should be given to components of the media since they control the physiology of the host plant and consequently influence host fungal relationships. Hepper (6) described methods for growing mycorrhizal seedlings axenically using agar, paper or glass wool as support. When ungerminated spores were used, all micronutrients were excluded as some of them depress spore germination. Different media have been used to grow plants axenically $(7,13,20)$. Nutrient concentrations in the media influence colonization of plants by AM fungi. Increased levels of $\mathrm{P}$ decrease root colonization (1). Additions of small amounts of $\mathrm{P}$ to agar media improved spore germination and germ tube growth of AM fungi (11). Menge et al. (8) mentioned that control of mycorrhizal colonization is linked to $\mathrm{P}$ in host tissue rather than in growing medium.

Mugnier and Mosse (12) demonstrated the importance of N concentration on root colonization. $\mathrm{N}$ concentration above 2 $\mathrm{mM}$ inhibited germ tubes growth. Under concentrations of 1 to $2 \mathrm{mM}$ germ tubes developed but passed across roots without becoming attached to their surface. When the nutrient medium contained less than $0.2 \mathrm{mM}$ of $\mathrm{N}$, the fungus showed some directional growth towards the root, and hypha attachment to the root surface was observed. Sugar concentration in media also affected root colonization by AM fungi. A low concentration of sucrose $4 \mathrm{~g} . \mathrm{l}^{-1}$ has increased germ tube growth (17) while

\footnotetext{
* Corresponding author. Mailing address: Embrapa Milho e Sorgo, Departamento de Microbiologia. 35701-970, Sete Lagoas, MG, Brasil. E-mail: bressan@cnpms.embrapa.br
} 
Mugnier and Mosse (12) observed that with more than 20g. $\mathrm{l}^{-1}$ of sucrose hypha growth was arrested and no attachment to the root surface was observed.

The objective of this study was to test the effects of different substrates and media composition on AM fungal colonization of micropropagated sweet potato seedlings.

\section{MATERIALS AND METHODS}

The experiment was conducted at the Soil and Water Science Department, University of Florida. The factorial experiment had a completely randomized design with 3 media substrates vermiculite, agar $0.8 \%$ and natrosol (hydroxiethyl celulose) and 3 media Hoagland and Arnon (7); Murashige and Skoog (13) and White (20), each supplemented or not with sucrose (3\%) (Table 1).

Growing shoots of sweet potato (Ipomoea batata), c.v. White Star, from greenhouse pot cultures were utilized as shoots source. Explants (shoot tips or stem section) were reduced to $0.5 \mathrm{~cm}$, a lenght easy to handle and to desinfestate with bleach (6\%) for $5 \mathrm{~min}$. Desinfested explants were washed 5 times with sterilized water.

Explants with one lateral bud were placed in Petri dishes $(100 \times 15 \mathrm{~mm})$ containing Murashige and Skoog medium (13) and pressed slightly into the medium with cut end submerged.

Table 1. Inorganic salt composition of Murashige and Skoog (13), Hoagland and Arnon (7) and White's (20) media.

\begin{tabular}{|c|c|c|c|}
\hline \multirow[b]{2}{*}{ Ingredients } & \multicolumn{3}{|c|}{ Media } \\
\hline & $\begin{array}{l}\text { Murashige } \\
\text { and Skoog }\end{array}$ & $\begin{array}{c}\text { Hoagland and } \\
\text { Arnon }\end{array}$ & White \\
\hline \multicolumn{4}{|c|}{ Macronutrients ( $\mu$ moles/liter) } \\
\hline Nitrogen & 60.0 & 15.0 & 2.0 \\
\hline $\mathrm{NH}_{4}^{+}$ & 20.6 & - & - \\
\hline $\mathrm{NO}_{3}^{-}$ & 39.4 & 15.0 & 2.0 \\
\hline Phosphorus & 20.0 & 1.0 & 0.1 \\
\hline Potassium & 1.3 & 6.0 & 1.7 \\
\hline Calcium & 3.0 & 5.0 & 1.2 \\
\hline Magnesium & 3.0 & 2.0 & 3.0 \\
\hline Sulfur & 3.2 & 2.0 & 4.5 \\
\hline \multicolumn{4}{|c|}{ Micronutrients ( $\mu$ moles/liter) } \\
\hline Boron & 100.0 & 46.3 & - \\
\hline Chlorine & $2,993.0$ & 10.9 & 870.0 \\
\hline Cobalt & 0.1 & - & - \\
\hline Cooper & 0.2 & 0.3 & - \\
\hline Iodine & 5.0 & - & 4.5 \\
\hline Iron & 10.0 & 9.0 & 10.0 \\
\hline Manganese & 103.0 & 10.9 & 30.0 \\
\hline Molybdenum & 1.1 & 0.1 & - \\
\hline Sodium & 3.2 & - & - \\
\hline Zinc & 3.0 & 0.8 & 9.0 \\
\hline
\end{tabular}

Plates with explants were incubated in 10/14 ligth/dark conditions $\left(52 \mu \mathrm{mol} . \mathrm{m}^{-2} . \mathrm{s}^{-1}\right)$ at $27 \pm 4^{\circ} \mathrm{C}$ for 2 weeks, after which they were transferred to Petri dishes containing the treatment combinations, and inoculated with five germinated Glomus etunicatum Becker \& Gerdeman ( INVAM FL S329) spores. Spores were surface desinfested with bleach (10\%) plus 1 drop of tween 20 during 5 minutes then washed 5 times with sterilized water. Desinfested spores were placed in water/agar medium $(0.8 \%)$ and incubated during 7 days in the dark at $27 \pm 3^{\circ} \mathrm{C}$ and observed every 2 days for spore germination. When hifa length was twice the spore diameter, spots containing five germinated spores were placed close to roots of axenic sweet potato seedlings.

After 6 weeks plants were removed gently from the plates and separated from the shoot. Plant height was recorded. Roots were stained according to Phillips and Hayman (14) and root colonization by AM fungi was evaluted by the gridline-intersect method (5). Hyphal growth in agar substrate media was evaluated weekly under optical microscopy at $60 \mathrm{x}$ magnification with a graduate lens.

Data were analyzed using the General Linear Model (GLM) procedure of SAS (15). Significance of treatments were evaluated by Duncan's test $(\mathrm{p}<0.05)$. Percentage root colonization was arcsine transformed prior to GLM procedure.

\section{RESULTS AND DICUSSION}

Hyphal grew randomly and no directional growth to the roots was observed. A significant difference $(\mathrm{p}<0.05)$ was found in hyphal growth between normal medium and that supplemented with sucrose (Fig. 1). Addition of sucrose (3\%) retarded hyphal growth in all media tested. However, low concentration of sucrose $\left(4 \mathrm{~g} .1^{-1}\right)$ has been shown to stimulate hyphal growth (17). These results suggest that the effect of exogenous sugar on hyphal growth is related to its concentration in the media. White's (20) medium permitted higher hyphal growth than other media, regardless of sucrose amendment. Hypha growth was only positively correlated to root colonization $(r=0.829)$ in White's (20) medium. Low P concentration in the medium has been reported to enhance hyphal growth $(9,16,18)$ and root colonization $(2,3,4,8)$. Therefore, the low concentration of $P$ in White's medium (Table 1) may have contributed to enhance hyphal growth and root colonization by Glomus etunicatum.

The low $\mathrm{N}$ concentration in the medium also has been reported to enhance AM colonization of roots $(9,10,11)$. The highest root colonization of sweet potato in White's medium may be partially attributed to low $\mathrm{N}$ concentration in this medium (Table 1). Root colonization was not observed in plants growing in Murashige and Skoog (13) and Hoagland and Arnon (7) media. The high $\mathrm{N}$ concentration in these media (Table 1) may have affected root colonization. These results suggest that 


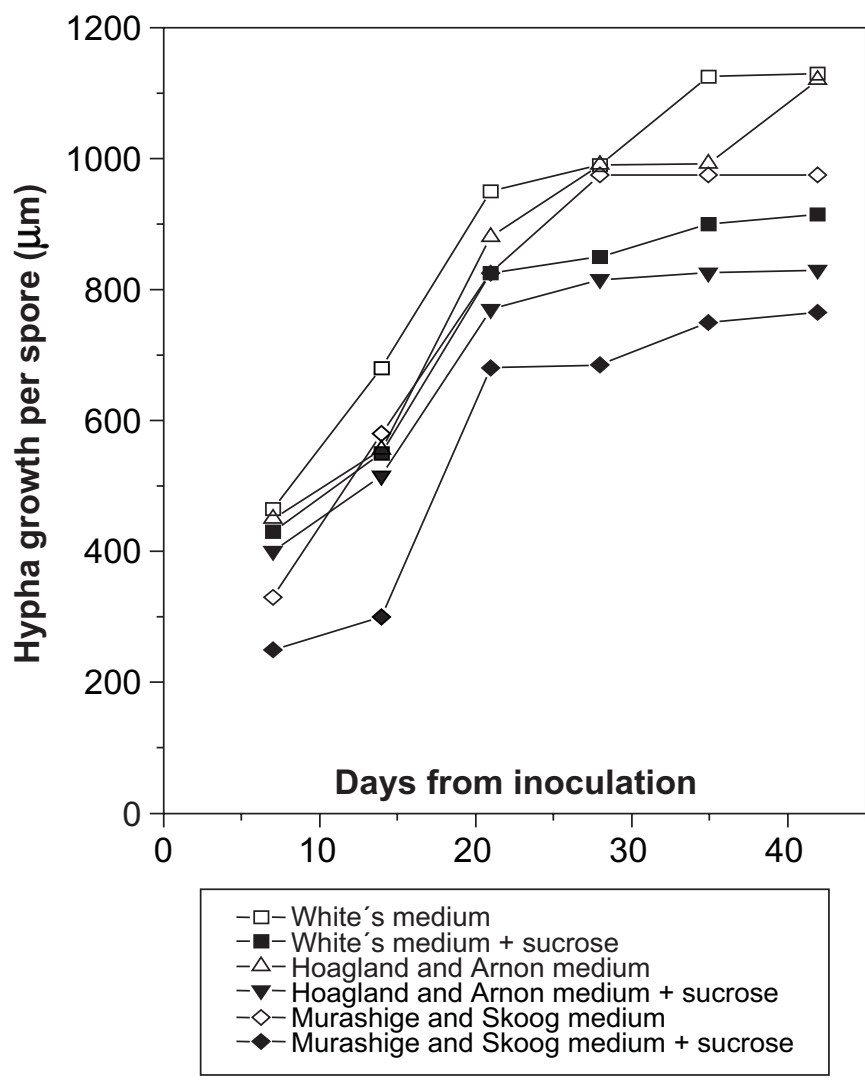

Figure 1. Effect of different media on hyphal growth Glomus etunicatum spores supplemented or not with $3 \%$ sucrose.

the effect of $\mathrm{N}$ on root colonization depends on its concentration in the medium.

The high concentration of inorganic nutrients in Murashige and Skoog (13) medium (Table 1), mainly $\mathrm{N}$ and P, stimulated plant growth. The lowest plant growth was observed in White's medium (20) due to its lower nutrient concentration. However, no significant difference $(\mathrm{p}<0.05)$ was observed between plant growth in Murashige and Skoog (13) and Hoagland and Arnon (7) media, and the addition of sucrose to the media did not affected plant growth (Fig. 2). Although, low concentration of nutrients in White's (20) medium (Table 1) promoted root colonization, the contribution of AM fungi to plant growth was not significant compared to higher levels of nutrients of the Murashige and Skoog (13) and Hoagland and Arnon (7) media.

Substrate type (vermiculite, agar and natrosol) affected plant growth in Murashige and Skoog (13) and White's (20) media (Fig. 2). Plants growing in the media had greater height when vermiculite was added. No significant difference ( $\mathrm{p} £ 0.05)$ was observed between agar and natrosol. The higher plant growth observed in vermiculite was likely due to improved air diffusion through the media.

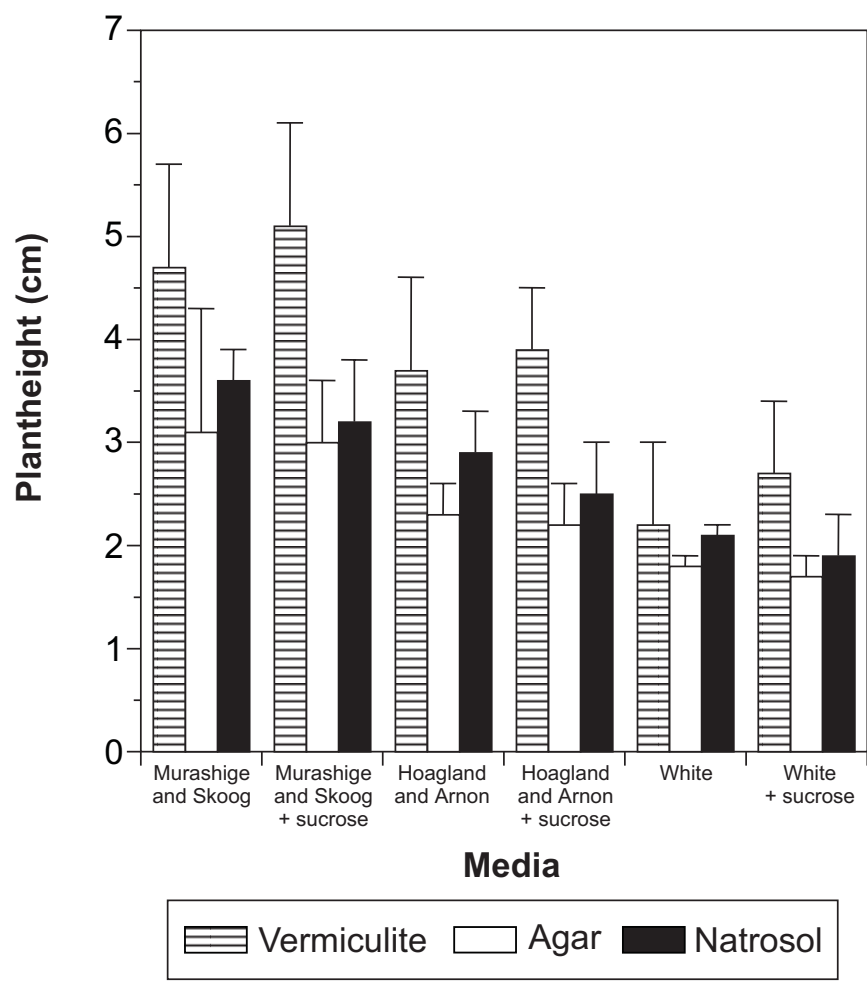

Figure 2. Effect of media substrate on sweet potato plant height. Bars indicate standard deviation of the mean.

The influence of the type of substrate on root colonization has not been reported. Root colonization was also significantly $(p<0.05)$ affected by the type of substrate. The highest percentage of root colonization was observed in Vermiculite, compared to Agar and Natrosol substrates (Table 2). In all substrates tested, root colonization was only observed in White's medium (20), regardless of sucrose amendment.

Table 2. Effect of the different media and substrate on AM mycorrhizal root colonization of sweet potato, c.v. White Star. Means of 16 replicates.

\begin{tabular}{lccc}
\hline \multirow{2}{*}{ Media } & \multicolumn{3}{c}{ Root colonization (\%) } \\
\cline { 2 - 4 } & Vermiculite & Agar & Natrosol \\
\hline Murashige and Skoog & - & - & - \\
Murashige and Skoog + Sucrose & - & - & - \\
Hoagland and Arnon & - & - & - \\
Hoagland and Arnon + Sucrose & - & - & - \\
White & $38 \mathrm{Aa}$ & $20 \mathrm{Ac}$ & $24 \mathrm{Ab}$ \\
White + Sucrose & $25 \mathrm{Ba}$ & $14 \mathrm{Bc}$ & $18 \mathrm{Bb}$ \\
\hline
\end{tabular}

Means within a column followed by the same capital letter, and within a row followed by the same lowercase letter do not differ significantly at $\mathrm{p}<0.05$, by Duncan's multiple range test. 
The results indicate that colonization of roots of micropropagated sweet potato by AM fungi is related to media composition and nutrient availability. However, media composition that enhances root colonization may reduce plant growth. In addition, the type of substrate can also affect the response of the plant to nutrient addition. Further research is needed to determine the nutrient combination and substrate to promote maximum plant growth.

\section{RESUMO}

\section{Fatores que afetam o desenvolvimento da planta e a colonização radicular “in vitro", da batata doce por Glomus etunicatum Becker \& Gerd.}

Os meios de Murashige e Skoog, Hoagland, Arnon e White, suplementados ou não com sacorose, e tendo como substratos vermiculita, ágar ou natrosol foram utilizados para avaliar seus efeitos sobre o desenvolvimento da batata doce, c.v. White Star, e sua colonização por Glomus etunicatum Becker \& Gerd. (isolado INVAM FL S329). A adição de sacorose (3\%) ao meio não afetou o desenvolvimento da planta, porém reduziu o crescimento das hifas de G. etunicatum e a colonização das raízes. A concentração de nutrientes dos meios utilizados mostrou efeitos contrastantes entre altura da planta, crescimento das hifas e colonização das raízes por G. etunicatum. A alta concentração de nutrientes no meio Murashige e Skoog estimulou o crescimento das plantas, reduziu o desenvolvimento das hifas e inibiu a colonização das raízes pelo fungo micorrízico. Plantas desenvolvidas em vermiculita mostraram maior desenvolvimento e maior colonização das raízes que as desenvolvidas em agar ou natrosol. Os resultados indicam que o desenvolvimento e a colonização "in vitro" da batata doce micropropagada é afetada pela composição do meio e pelo tipo de substrato.

Palavras-chave: micorriza arbuscular, micropropagação, meio de cultura, substrato

\section{REFERENCES}

1. Abbott, L.K.; Robson, A.D. The effect of VA mycorrhizae on plant growth. pp.113-130. In: POWELL, C.L.; BAGYARAJ, D.J. (Eds.). VA Mycorrhiza. Boca Raton, Florida: CRC Press, 1984. p.134-159.
2. Abbott, L.K.; Robson, A.D.; Doeboer, G. The effect of phosphorus on the formation of hyphae in soil by the vesicular-arbuscular fungus Glomus fasciculatum. New Phytol., 97: 437-446, 1984.

3. Bolan, N.S.; Robson, A.D.; Barrow, N.J. Increasing phosphorus supply can increase the infection of plant roots by vesicular-arbuscular mycorhizal fungi. Soil Biol. Biochem., 16: 419-420, 1984.

4. Bruce, A.; Smith, S.E.; Tester, M. The development of mycorrhizal infection in cucumber: effects on root growth, formation of entry points and growth of infection units. New Phytol., 124: 507-514, 1994.

5. Giovanetti, M.; Mosse, B. An evalution of techniques for measuring VA mycorrhizal infection in roots. New Phytol., 84: 489-500, 1980 .

6. Hepper, C.M. Techniques for studying the infection of plants by vesicular-arbuscular mycorrhizal fungi under axenic conditions. New Phytol., 88: 641-647, 1981.

7. Hoagland, D.R.; Arnon, H.I. The water-culture method for growing plants without soil. California Experimental Agriculture Station Circular. 347. Berkeley, 1950. 32p.

8. Menge, J.A.; Sterile, D.; Bayaraj, D.J.; Johnson, E.V.L.; Leonard, R.T. Phosphorus concentration in plants responsible for inhibition of mycorrhizai infection. New Phytol., 80: 575-578, 1978.

9. Miranda, J.C.C.; Harris, P.J.; Wild, A. Effects of soil and plant phosphorus concentration on vesicular-arbuscular mycorrhiza in sorghum plants. New Phytol., 112: 405-410, 1989.

10. Mosse, B.; Phillips, J.M. The influence of phosphate and other nutrients on the development of vesicular-arbuscular mycorrhiza in culture. J. Gen. Microbiol., 69: 157-166, 1971.

11. Mosse, B.; Advances in the study of vesicular-arbuscular mycorrhiza. Ann. Rev.Phytopathol., 11: 171-196, 1973.

12. Mugnier, J.; Mosse, B. Vesicular-arbuscular mycorrhizal infection in transformed root Ri TDNA roots grown axenically. Phytopathology, 77: 1045-1050, 1987.

13. Murashige, T.; Skoog, F. A revised medium for rapid growth and bioassays with tobacco cultures. Physiol. Plant., 15: 473-497, 1962.

14. Phillips, J.M.; Hayman, L.S. Improved procedure for clearing roots and staining parasitic and vesicuiar-arbuscular fungi for rapid assessment of infection. Trans. Br. Mycol. Soc., 55: 158-160, 1970 .

15. SAS INSTITUTE, SAS user's guide: statistics. Cary, NC. SAS Institute, mc., 1985. 928p.

16. Siqueira, J.O.; Hubbell, D.H.; Schenck, N.C. Spore germination and germ tube growth of a VAM fungus in vitro. Mycologia, 74(6): 952959, 1982.

17. Siqueira, J.O.; Hubell, D.H. Effect of organic substrate on germination and germ tube growth of VAM in vitro. Pesq. Agr. Bras., 21(5): 523527, 1986.

18. Thomson, B.D.; Robson, A.D.; Abbott, L.K. Soil mediated effects of phosphorus supply on the formation of mycorrhiza by Scutellospora calospora (Nicol \& Gerdeman) Walker \& Sanders. New Phytol., 118: 463-469, 1991.

20. White, P.R. A Handbook of plant tissue culture. Lancaster : Jacques Cotteil Press, 1963. 345p. 